\title{
Chinese First Deep Ice-Core Drilling Project DK-1 at Dome A, Antarctica (2011-2013): progress and performance
}

\author{
Nan ZHANG, ${ }^{1}$ Chunlei AN, ${ }^{2}$ Xiaopeng FAN, ${ }^{1}$ Guitao $\mathrm{SHI}^{2}{ }^{2}$ Chuanjin $\mathrm{LI}^{3}$ Jingfeng $\mathrm{LIU},{ }^{3}$ \\ Zhengyi HU, ${ }^{1}$ Pavel TALALAY, ${ }^{1}$ Youhong SUN, ${ }^{1}$ Yuansheng $\mathrm{LI}^{2}$ \\ ${ }^{1}$ Polar Research Center, Jilin University, Changchun, China \\ ${ }^{2}$ SOA Key Laboratory for Polar Science, Polar Research Institute of China, Shanghai, China \\ E-mail: liyuansheng@pric.gov.cn \\ ${ }^{3}$ State Key Laboratory of Cryospheric Sciences, Cold and Arid Regions Environmental and Engineering Research Institute, \\ Chinese Academy of Sciences, Lanzhou, China
}

\begin{abstract}
The Chinese First Deep Ice-Core Drilling Project DK-1 has commenced at Kunlun station in the Dome A region, the highest plateau in Antarctica. During the first season, within the 28th Chinese National Antarctic Research Expedition (CHINARE) 2011/12 the pilot hole was drilled and reamed in order to install a $100 \mathrm{~m}$ deep fiberglass casing. In the next season, 29th CHINARE 2012/13, the deep ice-core drilling system was installed, and all the auxiliary equipment was connected and commissioned. After filling the hole with drilling fluid (n-butyl acetate), three runs of 'wet' ice-core drilling were carried out and a depth of $131.24 \mathrm{~m}$ was reached. Drilling to the bedrock at the target depth of $\sim 3100 \mathrm{~m}$ is planned to be completed during a further four seasons. We describe the work in progress and the status of equipment for the Dome A drilling project.
\end{abstract}

KEYWORDS: ice coring, ice engineering

\section{INTRODUCTION}

Ice-core drilling on polar ice sheets is a research technique that was started in the mid-20th century. The resulting research findings are of notable scientific importance. The dust and suspended particulate in the Earth's atmosphere have been deposited on the Antarctic ice sheet through flow from the atmosphere, and capped by the growing ice shields. Additionally, the Antarctic ice sheet records information on variation of global climate and the history of climatic and environmental change caused by the influence of human activities. The Antarctic ice sheet is consequently known as the 'time capsule' (Motoyama, 2007). An ice core from the polar ice sheets is one of the best mediums for researching environmental, biological, chemical and physical processes in the Earth's system, with its advantages of high resolution, a large amount of information, high fidelity, long time series and high levels of cleanliness. Through ice-core studies, climate-change series of hundreds of thousands of years can be built. Ice-core studies provide an excellent method for investigating the past variation of global climate, monitoring the status and forecasting the future. Ice-core studies have made a major contribution to research on the variation of global climate (Qin, 1991; Petit and others, 1997; Yao, 1998; EPICA Community Members, 2004, 2006; Ren and others, 2009).

China formally implemented its first deep ice-core drilling project DK-1 in Antarctica in January 2012. The drilling site selected was at the Chinese Kunlun station $\left(80^{\circ} 25^{\prime} 01^{\prime \prime} \mathrm{S}, 77^{\circ} 06^{\prime} 58^{\prime \prime} \mathrm{E}\right)$, located in the Dome A region (Fig. 1), the highest plateau of the Antarctic ice sheet (Tang and others, 2012a). The elevation is nearly $4100 \mathrm{~m}$, the average ice-sheet thickness is $\sim 3100 \mathrm{~m}$ and the average annual temperature is $-58^{\circ} \mathrm{C}$. Horizontal movement of the ice is minimal and the snow accumulation rate is as low as $16 \mathrm{~mm}$ w.e. The region is the site with the lowest average annual temperature and smallest average annual snow deposition on Earth. Estimation of a depth-temperature distribution with a steady-state ice-dynamics model indicates that the ice at $3100 \mathrm{~m}$ depth might be $>1.1$ Ma old, with a temperature of $-8.4^{\circ} \mathrm{C}$ (Hou and others, 2007). Therefore, the Dome A region presents an opportunity to obtain the oldest continuous ice core with an age exceeding $1 \mathrm{Ma}$ (Xiao and others, 2008). This discovery aroused great interest within the international scientific community (Nature, 2006; Jones, 2007; Tang and others, 2012b).

The Chinese First Deep Ice-Core Drilling Project DK-1 is a path-finding program planned to be completed before 2018 . The first season of the project was carried out by the 28th Chinese National Antarctic Research Expedition (CHINARE) team in January 2012, with the main task of constructing a pilot hole. In the next season, in January 2013, the 29th CHINARE team installed a deep-ice 'wet' drill system and started coring operations. Due to logistical problems, drilling was not conducted in the 30th CHINARE but is planned to be continued in the following four seasons from 2014 to 2018.

\section{LOGISTICS AND DRILLING-SITE CONSTRUCTION}

The logistics work was begun by the 26th CHINARE team in January 2010. All cargo was shipped to Zhongshan station and unloaded on the Antarctic coast by the Chinese polar icebreaker Xuelong. The construction material for the icedrilling site and the drill equipment were loaded on sledges and transported from Zhongshan station to Kunlun station at Dome A, towed by snow vehicles for $\sim 1260 \mathrm{~km}$ (Fig. 2). Every season, about eight or nine vehicles were used to transport the material, drill equipment, fuel oil, food, generating equipment and camp containers (Fig. 3). Two types of vehicle are used to haul the cargo sledges: a Pisten Bully 300 vehicle with a maximum carrying load of 30-35 t for light cargo sledges, and a Caterpillar Challenger MT865B 


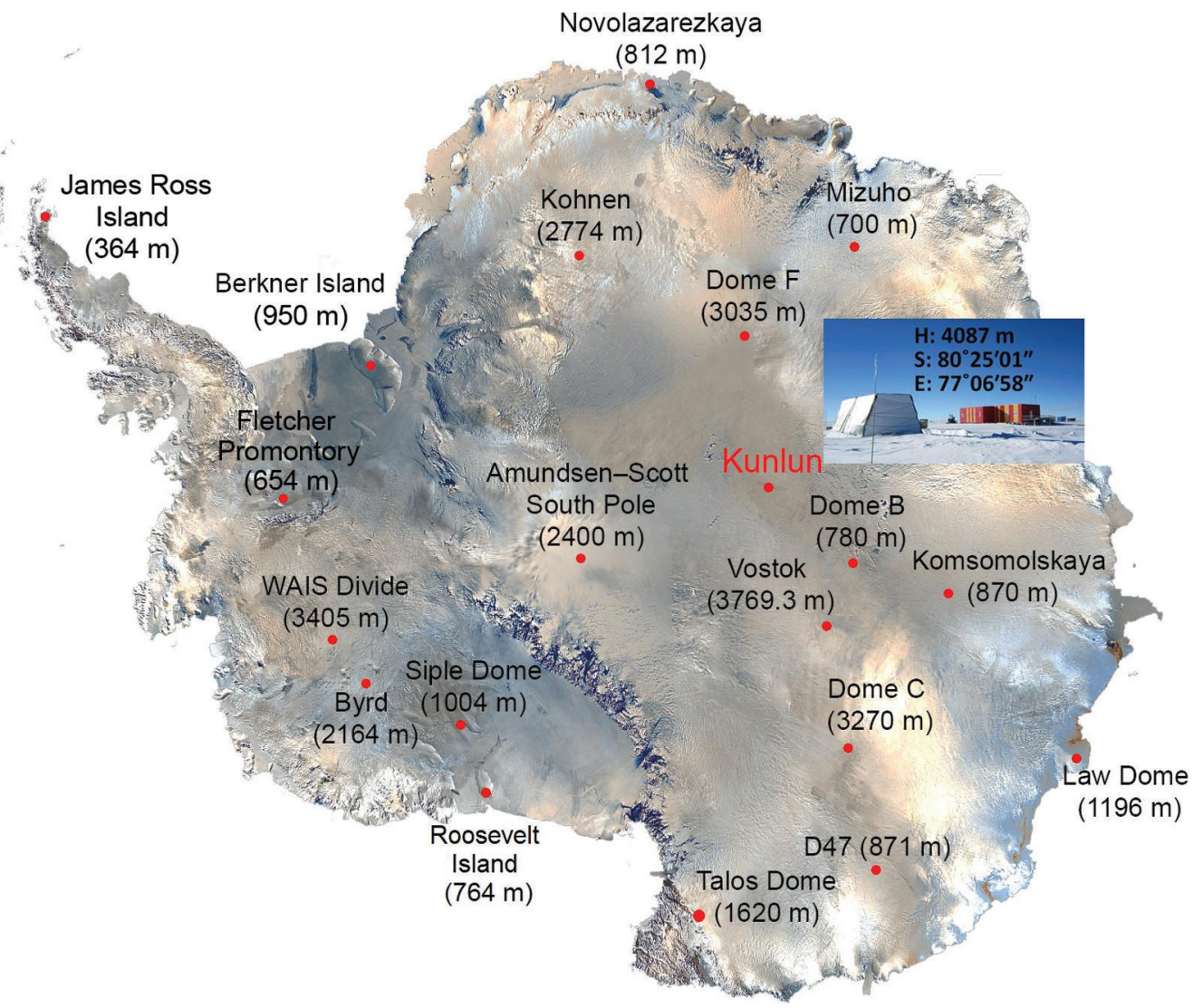

Fig. 1. Location of Kunlun station and other deep drilling sites in Antarctica.

with a maximum carrying load of 50-60 t for heavy cargo sledges. Because of extremely severe weather conditions with temperatures down to $-30^{\circ} \mathrm{C}$, and the lack of roads in inland Antarctica, the traverse from Zhongshan station to Kunlun station typically takes $\sim 20$ days (Fig. 4). Usually the traverse starts relatively late, in mid-December, due to logistical problems.

During the 2009/10 season, construction of the main field drilling site was completed. To prepare the drilling trench $(40 \mathrm{~m} \times 5 \mathrm{~m} \times 3 \mathrm{~m})$ beneath the surface, $>700 \mathrm{~m}^{3}$ of snow was excavated. In total, $\sim 20$ t of wooden base material and $36 \mathrm{t}$ of steel structure were used to construct the drilling trench framework (Fig. 5). The framework included 40 pillars and 19 steel roof trusses.

Through the 2010/11 season (27th CHINARE), the base of the floor was paved and most of the pit for the mast slot was excavated. For the floor construction, wooden beams with sectional dimensions of $200 \mathrm{~mm} \times 200 \mathrm{~mm}$ were used as base beams, and wooden braces with sectional dimensions of $50 \mathrm{~mm} \times 100 \mathrm{~mm}$ were used as beam supports. The wooden beams and braces were watered to freeze and fix to the snow surface. Polyethylene plastic foam insulation boards were paved between the beams (Fig. 6a). Compatibility of the insulation boards with the suggested drilling fluid, $n$-butyl acetate, was a concern. Spilling the fluid on the floor could eventually destroy the insulation. It was well known that $n$-butyl acetate is a very aggressive solvent (Talalay and Gundestrup, 1999). There are no elastomers that can operate in $n$-butyl acetate for a long time. On the other hand, some plastics (e.g. polypropylene, Teflon, polyethylene, Kevlar, nylon) are recommended materials for using with $n$-butyl acetate, as they are unlikely to be destroyed in the fluid. Polyethylene foam board was therefore chosen as the isolation material for the drilling shelter floor. Simple short-term tests confirmed that $n$-butyl acetate has no effect on this material.

After construction of the floor base, a sector-shaped mast pit $(7.4 \mathrm{~m} \times 0.6 \mathrm{~m} \times 9.6 \mathrm{~m})$ was excavated (Fig. $6 \mathrm{~b})$. During the 2011/12 season (28th CHINARE), the interior infrastructure of the drilling site was completed and wooden stairs and an entrance were built.

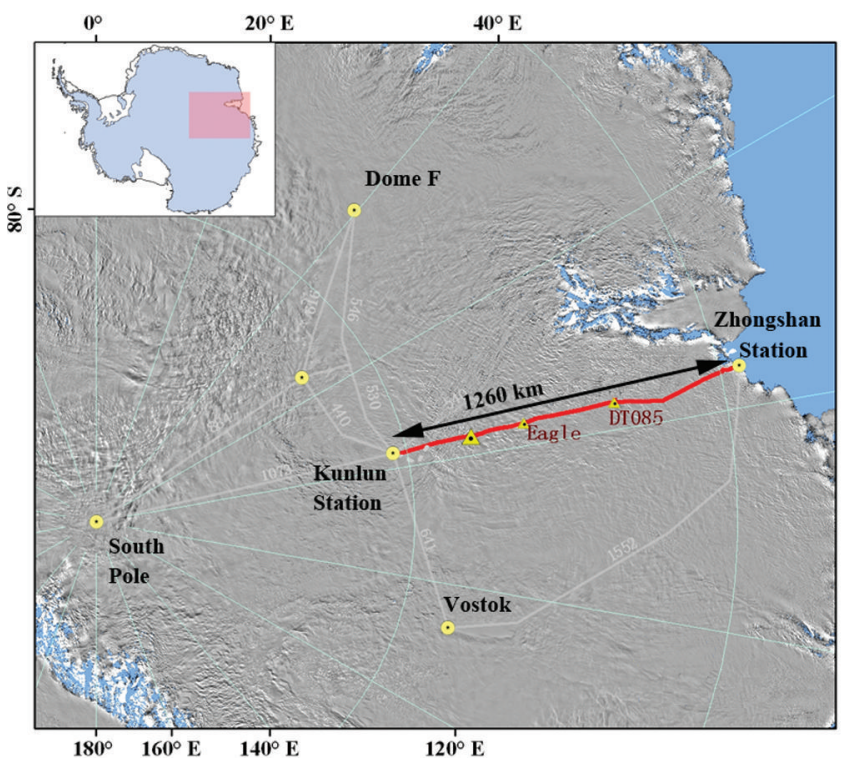

Fig. 2. Traverse route from Zhongshan station to Kunlun station. 


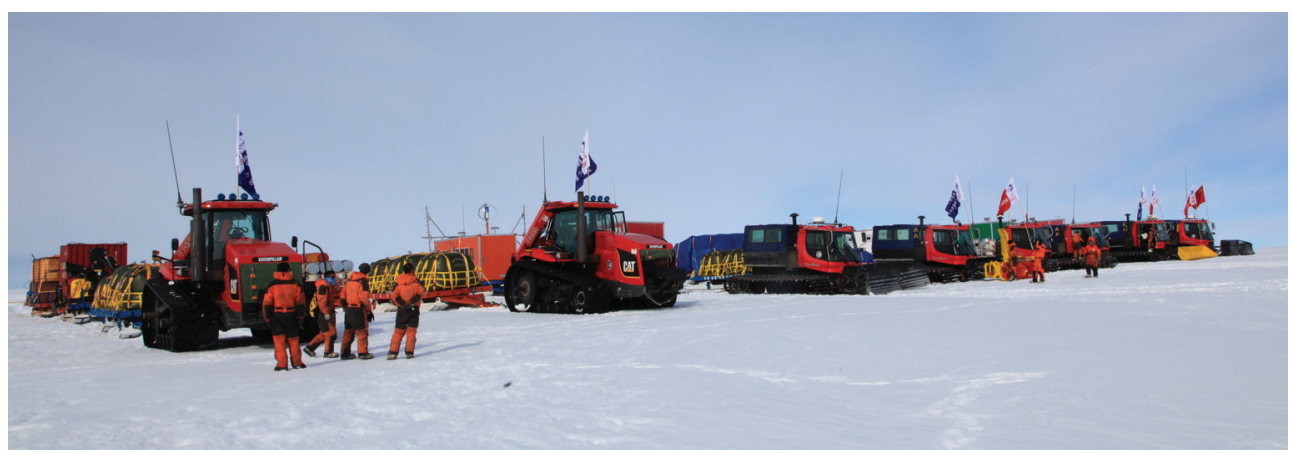

Fig. 3. Transportation traverse ready to go (16 December 2012; inland team departure point $8 \mathrm{~km}$ from Zhongshan station).

During the 2012/13 season (29th CHINARE) a control room, a maintenance workshop for the drilling trench and a core-processing room were excavated and constructed. The electrical system was installed, and the mast pit was deepened to the final depth of $9.6 \mathrm{~m}$. The control room and the workshop were built with a steel frame and insulation boards (Fig. 7a and b). The core-processing trench, $40 \mathrm{~m}$ long and $8 \mathrm{~m}$ wide, was excavated and covered by the same kind of framework as the drilling trench (Fig. 7c). The drilling and core-processing trenches were connected by an $8.7 \mathrm{~m} \times 3 \mathrm{~m}$ tunnel. A generator with a nominal power of $80 \mathrm{~kW}$ was built into a specially designed container installed at the surface. The generator was transported on a sledge. It provided power for drilling, auxiliary equipment, heating and lighting.

By the end of the 2012/13 summer season, all the materials and equipment had been installed in the appropriate place and the drilling site construction had been completed (Fig. 8).

\section{FIRST DRILLING SEASON: 2011/12}

Operations during the first drilling season at Kunlun station, 2011/12, were delivered within 21 days (including 16 days for pilot-hole construction) in three phases (An and $\mathrm{Li}$, unpublished): (1) shallow drilling of the pilot hole, (2) reaming and (3) casing setting (Fig. 9; Table 1).

\subsection{Shallow ice-core drilling}

The first phase included conventional shallow drilling with the electromechanical auger ice-core drill (Model D-3, $600 \mathrm{M}$ type) which was purchased by the Polar Research Institute of China from the Geo Tecs Company, Nagoya, Japan. The drill's design concept has been used before by

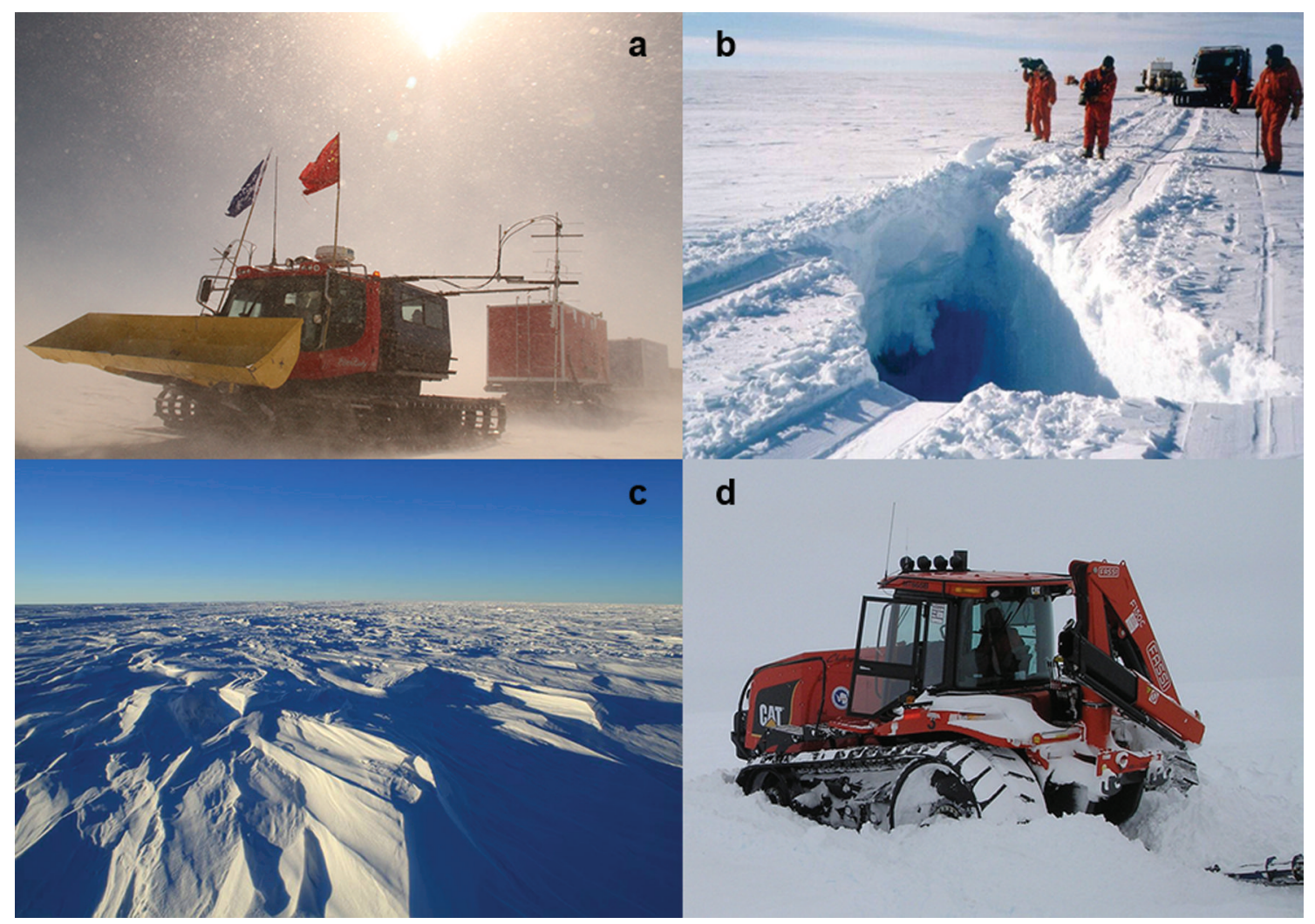

Fig. 4. Severe weather and road conditions on the way from Zhongshan station to Kunlun station: (a) traversing in blowing snow with low visibility; (b) snow bridge collapse after crossing crevasse on route; (c) sastrugi ( $1 \mathrm{~m}$ high) on route; and (d) heavy soft snow area inland ( $1000 \mathrm{~km}$ from Zhongshan station). 


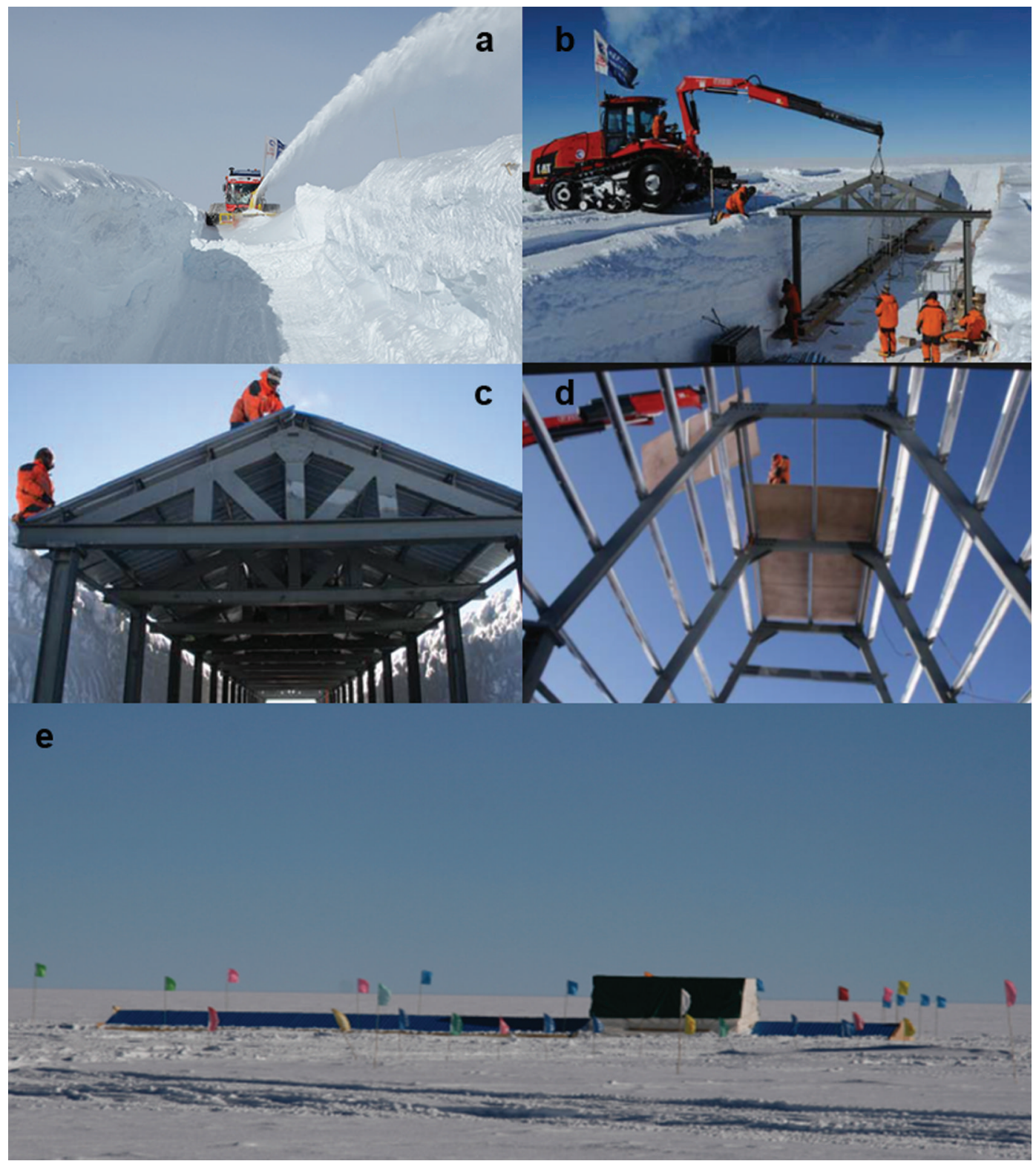

Fig. 5. Construction of the drilling trench framework. (a) Drilling trench excavation; (b) steel structure installation; (c, d) roof installation; and (e) exterior of drilling trench.

other shallow ice-core drilling operators. The drill contains cable termination, leaf spring anti-torque system, driven section and double core barrel. Chips, lifted by the inner auger through the window on top of the tube, drop on the plastic plate that separates the core barrel into two parts: one to hold the core and the other for chips (Table 2).

In total, 118 coring runs were undertaken using a drill bit of $135 \mathrm{~mm}$ outer diameter (OD) and $96.4 \mathrm{~mm}$ inner

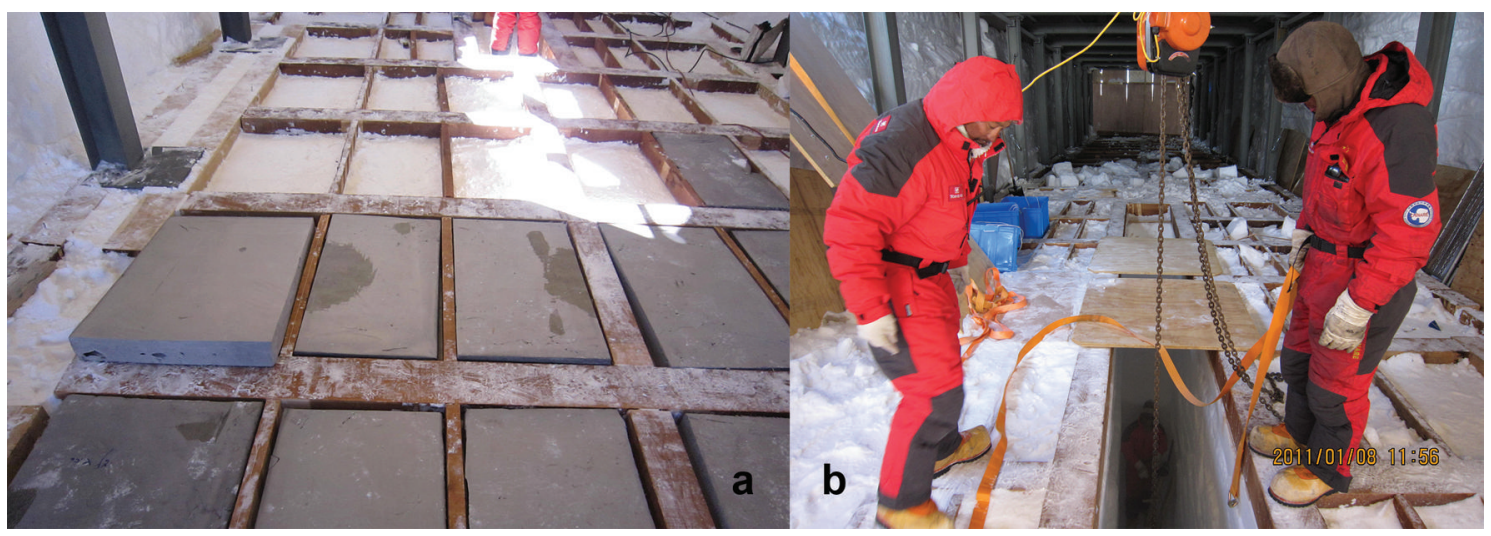

Fig. 6. (a) Floor base made from insulated paving and wood beam. (b) Mast pit excavation. 


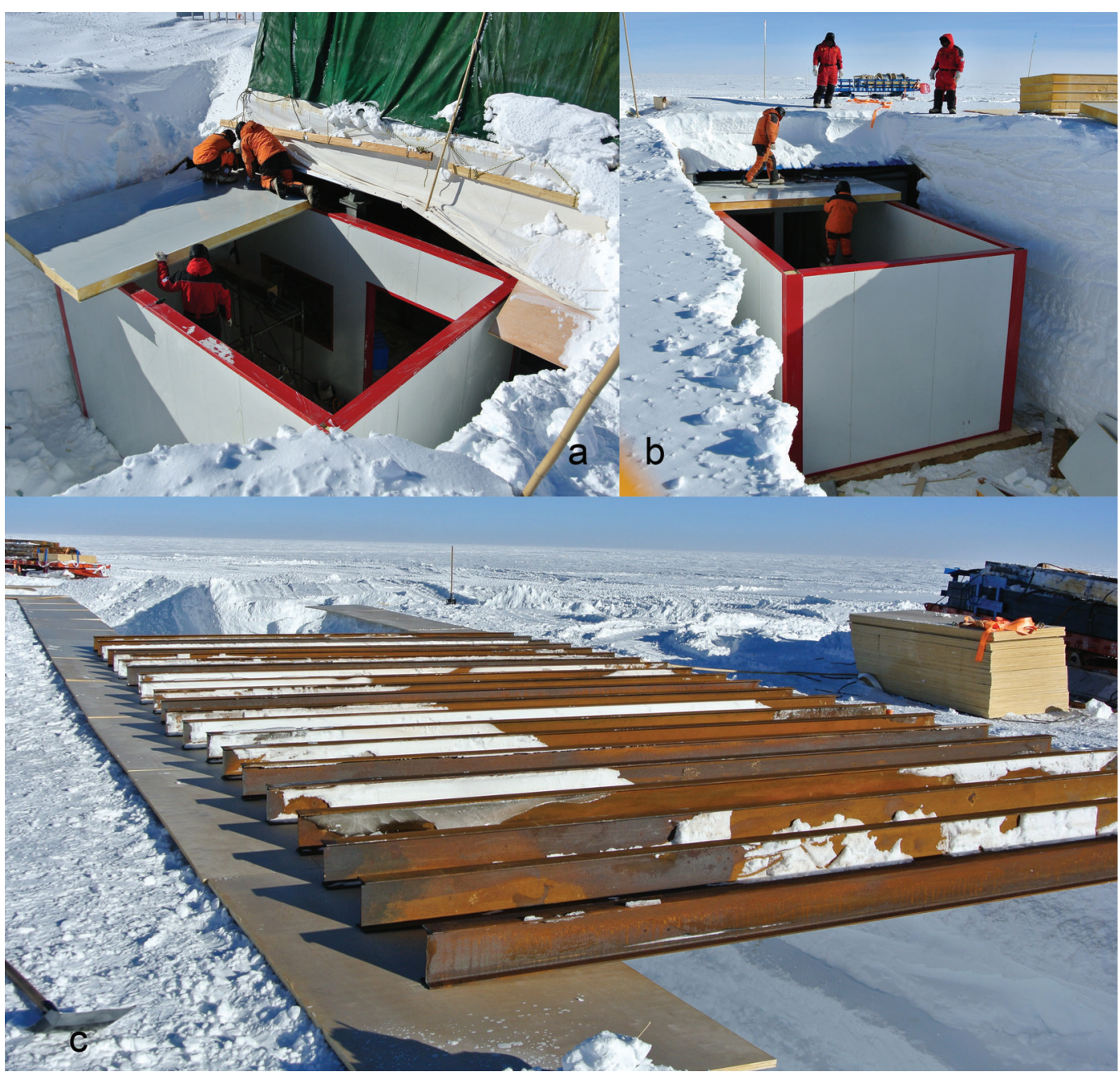

Fig. 7. Construction of (a) control room, (b) maintenance workshop and (c) core-processing room.

diameter (ID). The final depth of the 'dry' hole was $120.79 \mathrm{~m}$, with an average core run of $1.024 \mathrm{~m}$ (Fig. 10). The total drilling time was 51.5 hours. The depth of the coring run decreased from $1.2-1.4 \mathrm{~m}$ to $0.5-0.9 \mathrm{~m}$, deeper than the firn/ice transition $(\sim 100 \mathrm{~m})$ because of the increasing density and tensile strength of the upper snow/firn/ ice structure. The drilling efficiency and the core length of each run also decreased with depth (Fig. 11).

The drill bit rotation speed down to $20 \mathrm{~m}$ depth was maintained at $\sim 40 \mathrm{rpm}$. Beyond $20 \mathrm{~m}$, it was increased to $60 \mathrm{rpm}$ ( $\max 80 \mathrm{rpm})$, and the penetration rate was controlled in the range $6-8 \mathrm{~m} \mathrm{~h}^{-1}$ (Fig. 12). At depths exceeding $100 \mathrm{~m}$, the penetration rate dropped to $4-6 \mathrm{~m} \mathrm{~h}^{-1}$. Under normal drilling conditions, the motor current was in the

Table 1. Progress of the first drilling season at Kunlun station

\begin{tabular}{lc}
\hline Item & Date (2012) \\
\hline Pilot-hole drilling and coring & $7-14$ Jan. \\
Borehole 1st reaming & $14-17$ Jan. \\
Borehole 2nd reaming & $18-20$ Jan. \\
Borehole 3rd reaming & $20-22$ Jan. \\
Casing installed & 22 Jan.
\end{tabular}

range 0.6-1.2 A. When the chip chamber was full, however, the current could exceed 1.2 $\mathrm{A}$ and the drill process had to be stopped. Cutters with a $35^{\circ} \mathrm{C}$ rake angle were used.

During the drilling process, some problems were encountered:

In the upper snow formations, the core was not always recovered, because of the loose formation. When the lifting speed was reduced, it became possible to recover the core. Several times the anti-torque system had to be adjusted because leaf springs slipped in the hole or were too tight, and the drill could not reach the bottom to cut the ice.

The position of the plastic plate that separates the chip chamber from the core barrel requires a means of achieving finer adjustment. The plate position was changed by leveraging its position with a wooden stick and using line-of-sight and experience. At the beginning, the ratio between core barrel and chip chamber was $\sim 1$ : 1. With increasing depth and snow-firn density, this ratio was adjusted to $\sim 1: 1.17$ from a depth of $63 \mathrm{~m}$ to the final depth.

During the drilling process, the cutters were changed twice because degradation of the penetration rate indicated that the cutting edge was blunt. After changing cutters, the penetration rate was restored. 


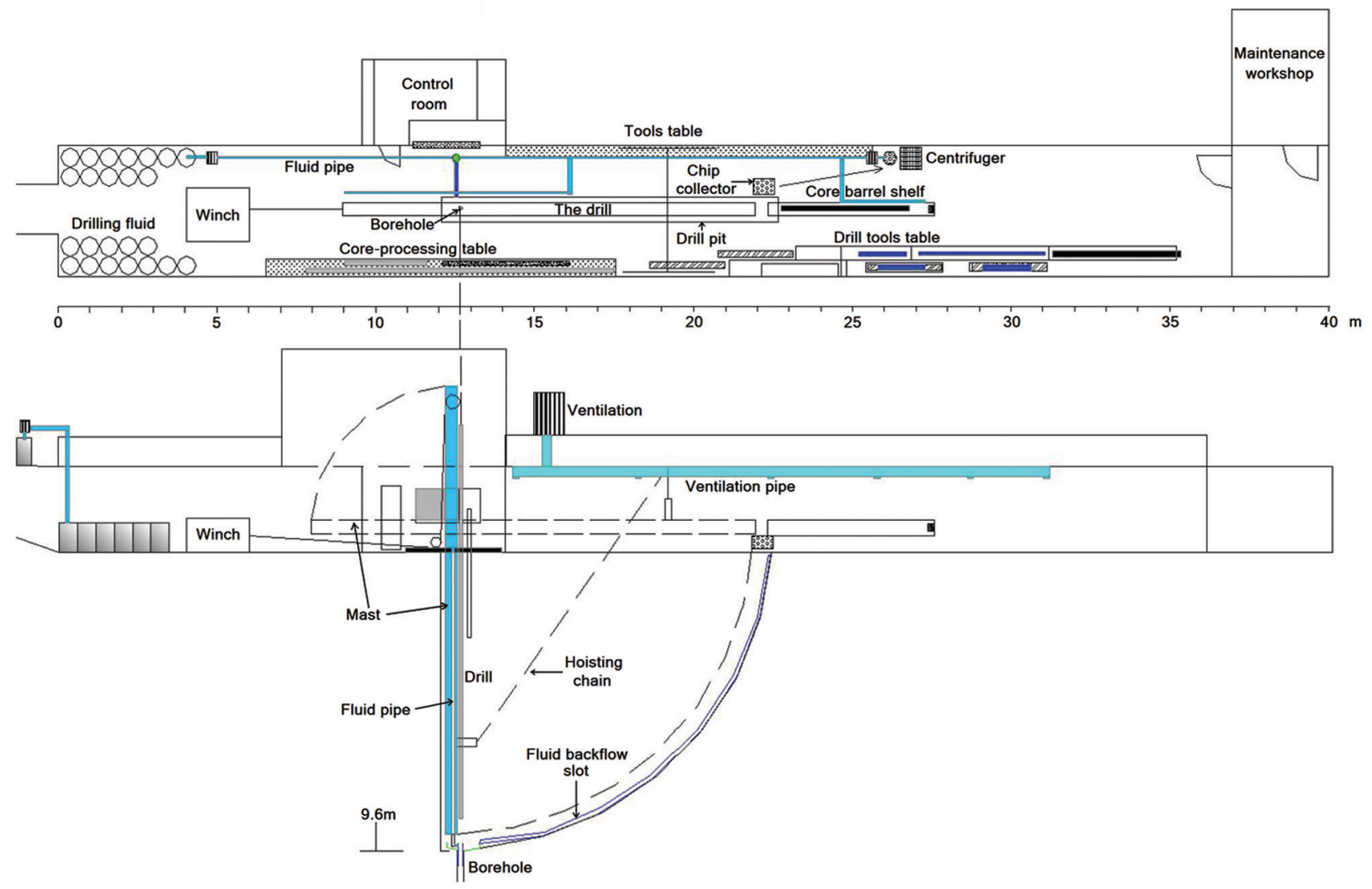

Fig. 8. Schematic of drilling trench.

Finally, an ice-core fracture problem was identified when drilling at greater depths. Down to $73 \mathrm{~m}$ depth, the recovered ice core was usually in one piece, but further down the core was broken into two or three pieces at right angles to the axis because of higher ice brittleness. There were visible fracture cracks at the surface of the core.

Table 2. Technical parameters of electromechanical shallow ice-core drill (Operating manual for the shallow ice core drill type D-3. 2011. Geo Tecs Co. Ltd, Nagoya)

Drill Main parameters

Anti-torque Drive part

Jacket Core barrel

Drill bit

Reaming drill

Winch

Mast

Cable Control panel

\section{Main parameters} Cable drum Motor Main parameters Pulley

Main parameters Control box for drill

Control box for winch
Type: Model D-3, 600M; whole length $3359 \mathrm{~mm}$; weight $50.5 \mathrm{~kg}$; core $95 \mathrm{~mm}$ OD in $1000 \mathrm{~mm}$ core length in one shot drilling

Leaf spring: 3 pcs, $599 \mathrm{~mm}$ long, $2.5 \mathrm{~mm}$ thick, $30 \mathrm{~mm}$ wide

Motor: permanent magnet-type d.c., 200 V/500 W, 4000 rpm; decelerator: harmonic drive system, reduction ratio $1 / 80$; output $50 \mathrm{rpm}$

$125 \mathrm{~mm}$ OD, $2.5 \mathrm{~mm}$ thick, $2580 \mathrm{~mm}$ long

$101.6 \mathrm{~mm}$ OD, $2.1 \mathrm{~mm}$ thick, $2529 \mathrm{~mm}$ long, 3 spiral windings; cutter mount: $125 \mathrm{~mm}$ OD, $96.4 \mathrm{~mm}$ ID;

$135 \mathrm{~mm}$ OD; qty of cutter: 3; face angle of cutter: $35^{\circ}$; qty of core catcher: 3 ; qty of adjusting shoe of cutting pitch: 3

1st reaming: $180 \mathrm{~mm}$ OD, length of chip chamber $2260 \mathrm{~mm}$

2nd reaming: $215 \mathrm{~mm}$ OD, length of chip chamber $760 \mathrm{~mm}$

3rd reaming: $245 \mathrm{~mm}$ OD, length of chip chamber $1560 \mathrm{~mm}$

Model W-4 type; lifting ability: $60 \mathrm{~kg}$ (max $120 \mathrm{~kg}$ ); lifting speed: $25-45 \mathrm{~m} \mathrm{~min}^{-1}$ $300 \mathrm{~mm}$ ID, $300 \mathrm{~mm}$ width, $500 \mathrm{~mm}$ OD

3-phase induction motor; available inverter control; 3-phase $200 \mathrm{~V}, 1.5 \mathrm{~kW}$ with magnet brake M-4 rotary type; ground height $3300 \mathrm{~mm}$ (at center of pulley) $350 \mathrm{~mm}$ OD

Armored cable 4-H-220K, $5.66 \mathrm{~mm}$ OD, 4 cores, $600 \mathrm{~m}$ long

Input power: $200 \mathrm{~V}$ a.c.; output: drill motor, 0-200 V d.c.; component parts: slide transformer, a.c./ d.c. rectifier, inverter, voltmeter

Output: winch motor inverter type, $200 \mathrm{~V}$ a.c./1.5 KW; inverter: single-phase input and 3-phase output type; component parts: inverter, voltmeter, ammeter, lever switch, brake unit 


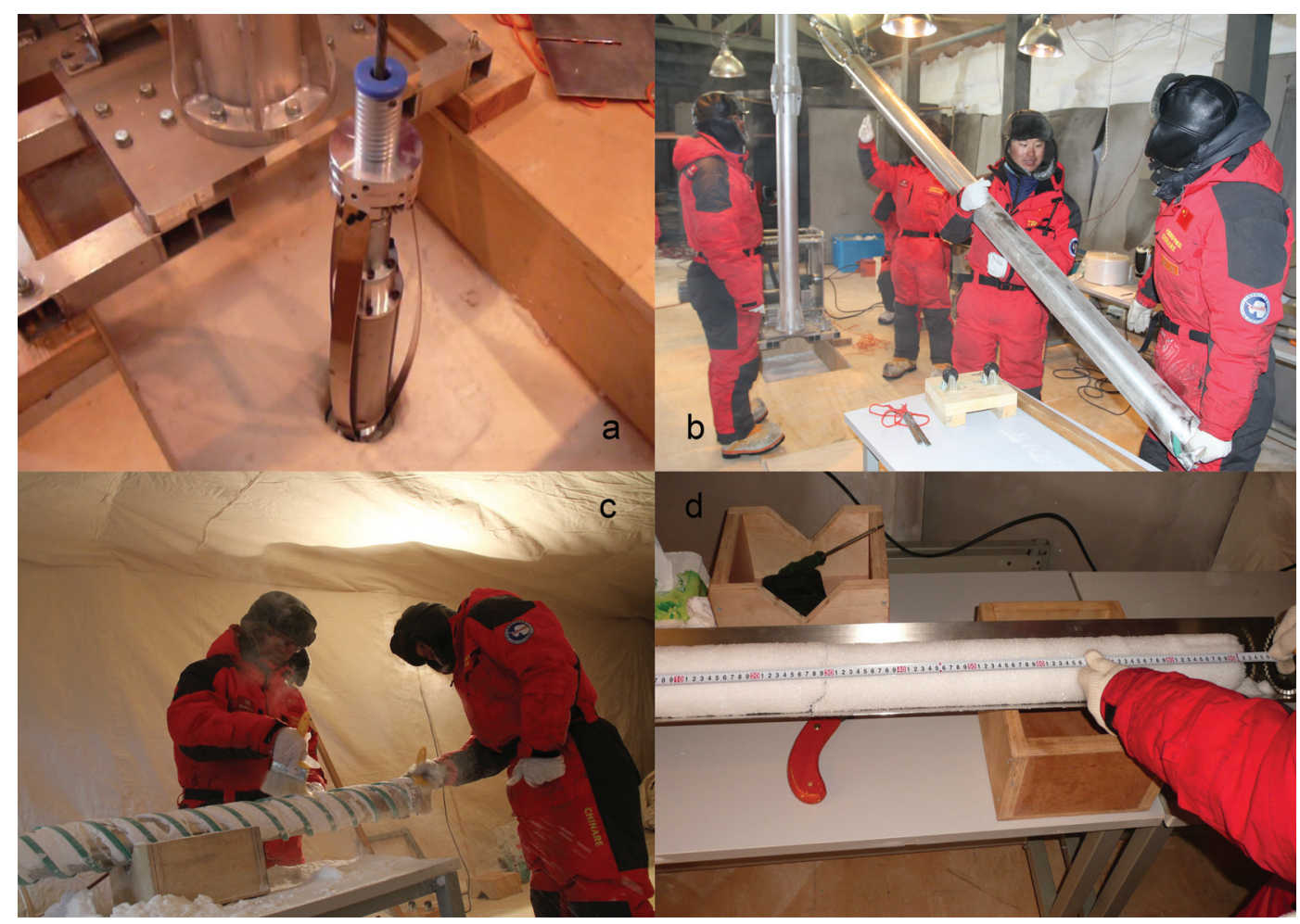

Fig. 9. Working events during the first drilling season at Kunlun station: (a) lowering shallow drill; (b) lifting the drill; (c) cleaning the drill and removing the core; and (d) core processing.

Table 3. Reaming parameters

Reaming Final depth Number of Diameter Average run Duration runs

\begin{tabular}{lccccc} 
& $\mathrm{m}$ & & $\mathrm{mm}$ & $\mathrm{m}$ & hours \\
\hline 1st & 104.05 & 99 & 180 & 1.05 & 26 \\
2nd & 102.08 & 65 & 215 & 1.53 & 17 \\
3rd & 100.03 & 45 & 245 & 2.22 & 14 \\
\hline
\end{tabular}

\subsection{Reaming}

The second phase involved reaming the hole in three steps (Table 3). The same shallow electromechanical auger icecore drill was used, but, instead of the conventional double core barrel, a special reamer with a chip container was installed. The bit rotation speed was adjusted to $11 \mathrm{rpm}$, and the reaming had a higher penetration rate than core drilling (Fig. 13). As with the shallow ice-core drilling, the reaming penetration rate decreased with depth.

To avoid dropping the chips during reaming, duct tape was wrapped around the top of the chip container to seal the clearance between it and the borehole wall. This action reduced the problem but did not completely solve it. As some of the ice cuttings dropped onto the bottom of the hole during the reaming process, recovery of the ice chips was carried out after each reaming size, using the standard configuration of the shallow ice-core drill. After removing the ice chips, a $30 \mathrm{~mm}$ long core was obtained, which indicated that the bottom was clean. The final depth of the pilot hole after cleaning was $120.79 \mathrm{~m}$.

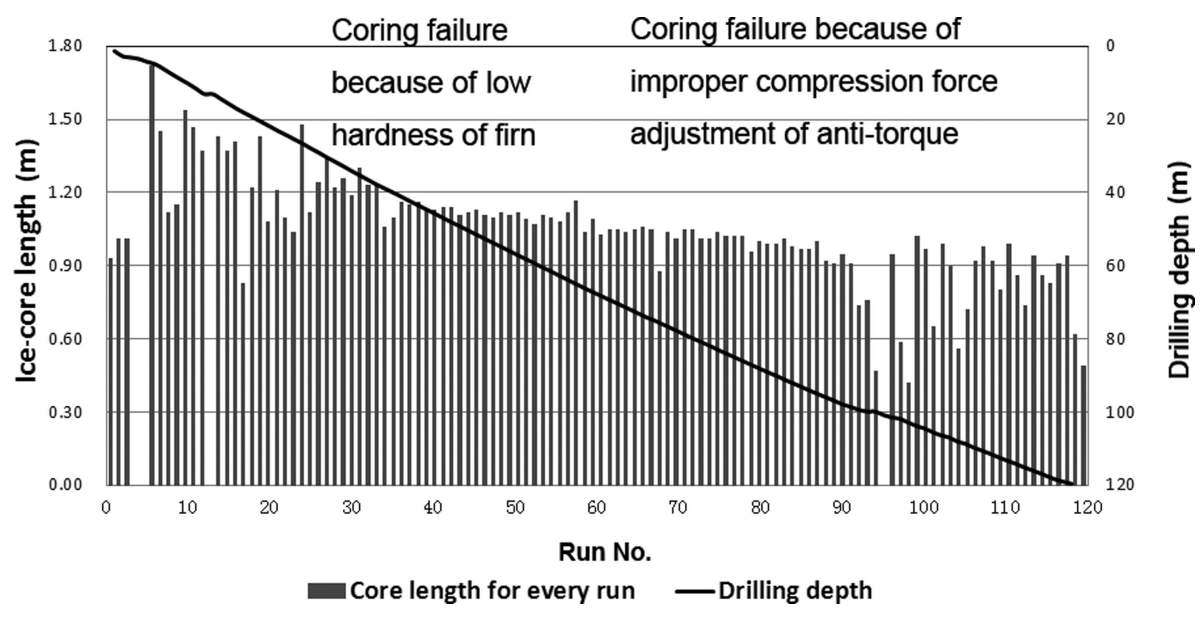

Fig. 10. Drilling process ('dry' auger drilling). 


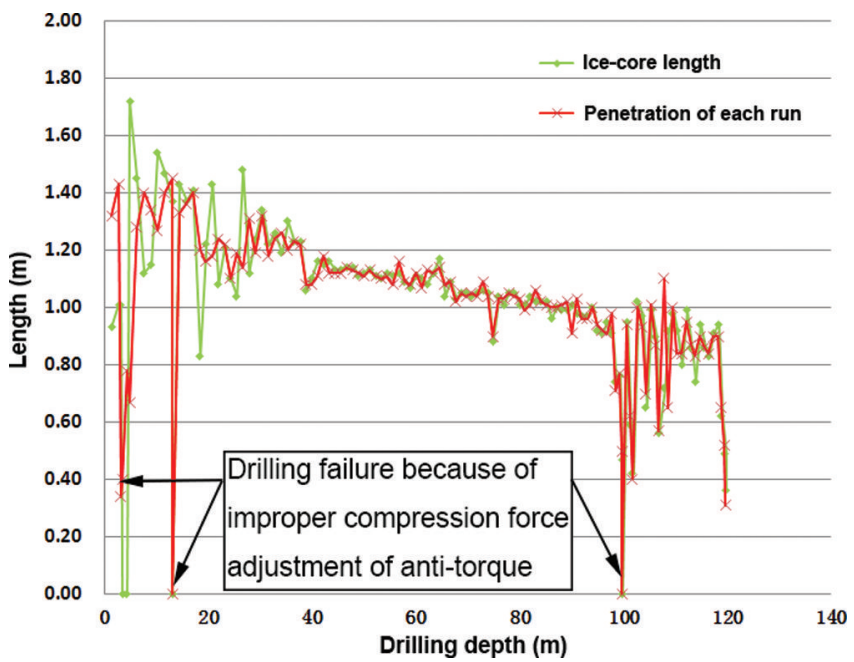

Fig. 11. Run and core length vs depth ('dry' auger drilling).

The borehole structure achieved at the end of the season is shown in Figure 14. The lower part of the hole $(\sim 16 \mathrm{~m})$ was uncased in order to ensure that the anti-torque system fitted to the deep ice-core drill could contact with the borehole wall and hold the upper non-rotated part of the drill.

\subsection{Casing}

Seventeen $6 \mathrm{~m}$ long fiberglass pipes used for casing were installed in the pilot hole to $\sim 100 \mathrm{~m}$ depth to prevent drilling fluid from leaking into the permeable snow-firn formation during drilling. The average speed for lowering the casing pipe was kept at $0.3 \mathrm{~m} \mathrm{~min}^{-1}$. The pipes were screwed together with a four-threaded connection $(\mathrm{M} 218 \times 6 \mathrm{~mm})$ and sealed with fluoroplastic tape.

\section{SECOND DRILLING SEASON: 2012/13}

The second field season, 2012/13, was shortened to only 13 days. Excavation of the mast pit took five of these days. Activities in the second season can be divided into three phases: (1) installation of the deep ice-core drilling system; (2) equipment connection, debugging and testing; and (3) start of deep ice-core drilling (Fig. 15; Table 4).

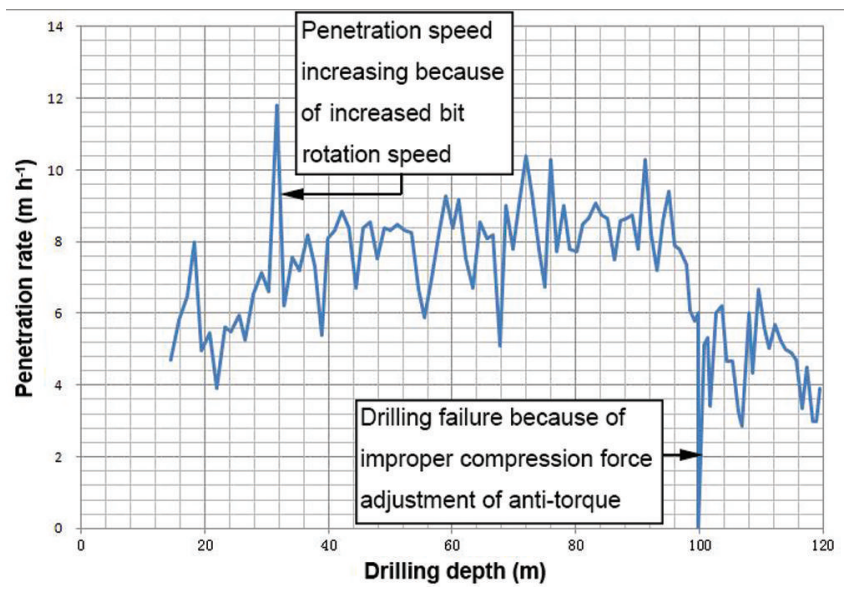

Fig. 12. Penetration rate vs depth ('dry' auger drilling).

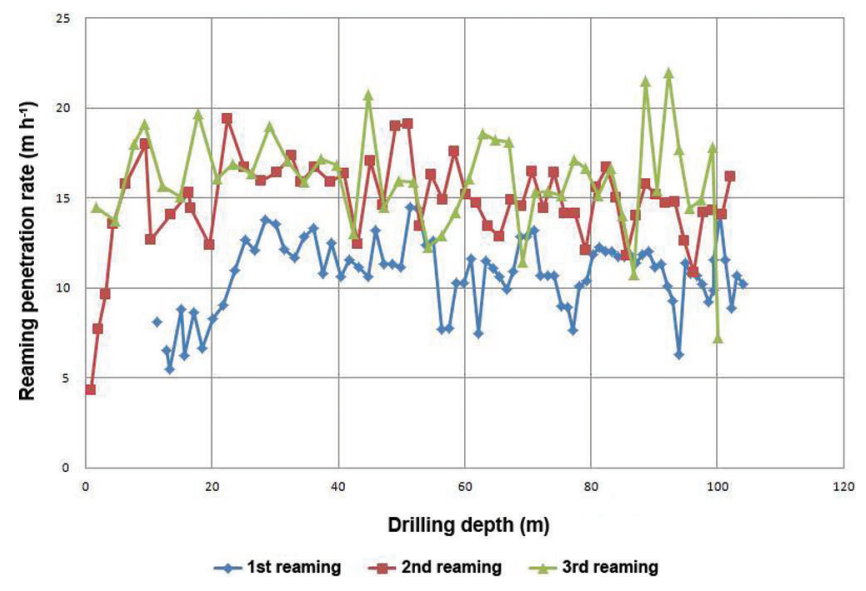

Fig. 13. Reaming penetration rate vs depth.

\subsection{Equipment installation}

To continue 'wet' deep drilling, the following equipment was installed in the drill trench:

1. Mast and base including the mast top with top pulley and turnabout pulley on the base;

2. Winch, on which $4000 \mathrm{~m}$ of armored cable have been coiled through a braking device with dynamometer (spooling cable tension was kept at $\sim 5 \mathrm{kN}$ );

3. Electromechanical CHINARE/Japanese Antarctic Research Expedition (JARE) deep ice drill, jointly developed by the Polar Research Institute of China and the Geo Tecs Company, Nagoya, Japan (Table 5);

4. Control system (power supply, winch control panel, drill motor control panel);

5. Auxiliary equipment including ice working tables, chip centrifuge, drill and core clean devices, and ventilation system.

The design of the electromechanical CHINARE/JARE deep ice drill is similar to that of the JARE deep drill used at Dome F (Motoyama, 2007), except for the size of the chip chamber, the anti-torque system and some other parts. For

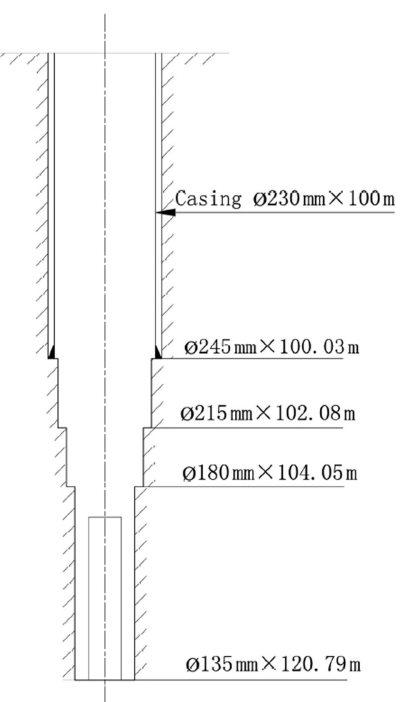

Fig. 14. Borehole structure as of 22 January 2013. $\varnothing$ is diameter. 


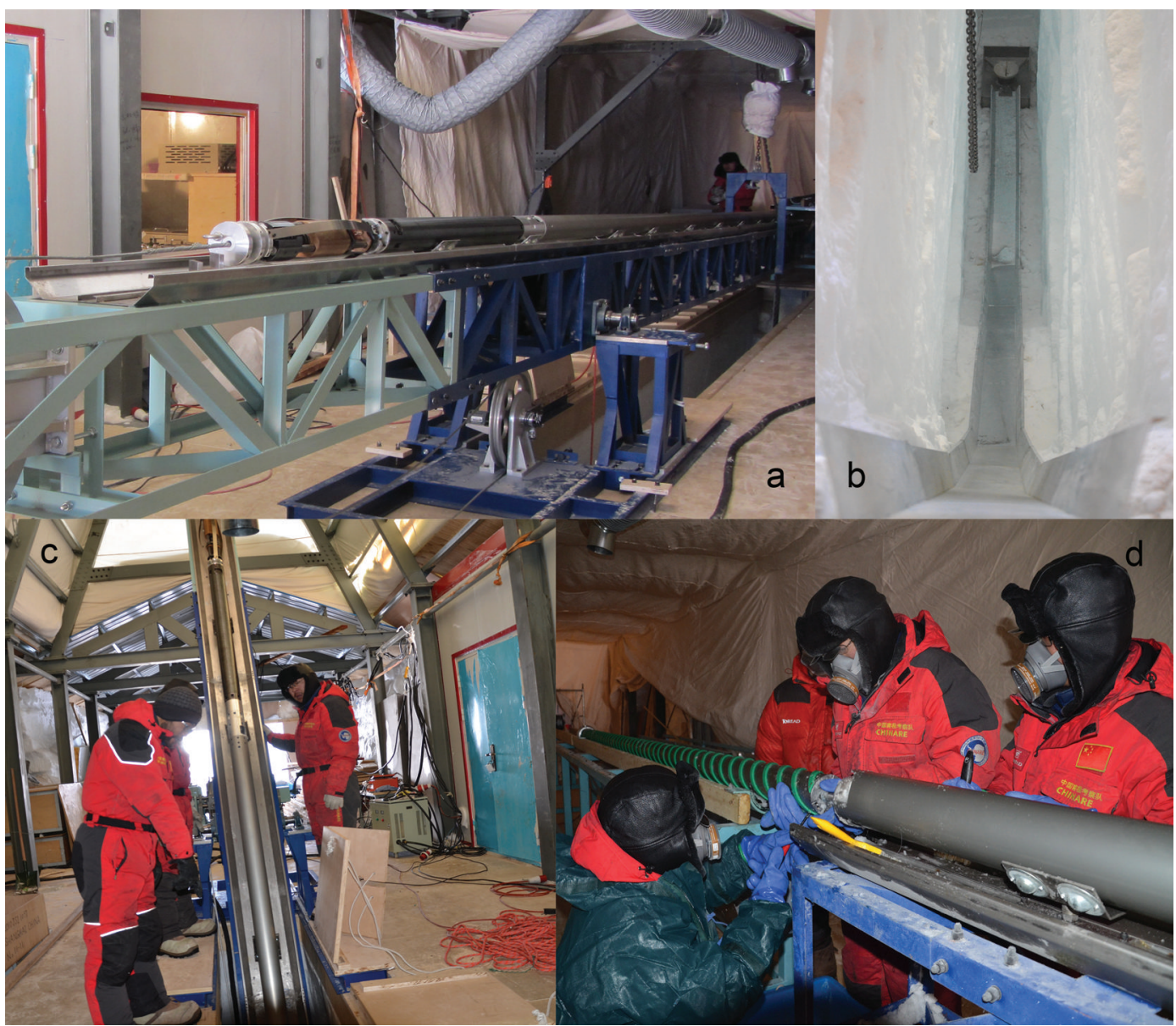

Fig. 15. Working events during the second drilling season at Kunlun station: (a) drill rig assembly; (b) fluid back-flow slot installation; (c) lowering the drill; and (d) cleaning the drill and removing the core.

example, the chip chamber of the CHINARE/JARE deep ice drill is shorter by $533 \mathrm{~mm}$ and larger in ID by $2 \mathrm{~mm}$ than the JARE drill.

\subsection{Equipment connection, debugging and testing}

All electrical and communication systems were connected and checked. The external sensors (load cell and temperature gauge), limit switch and depth-meter were installed and connected to the control unit. After debugging, the deep icecore drill was lowered and lifted several times in the hole. The relationship between the cable setting speed with a

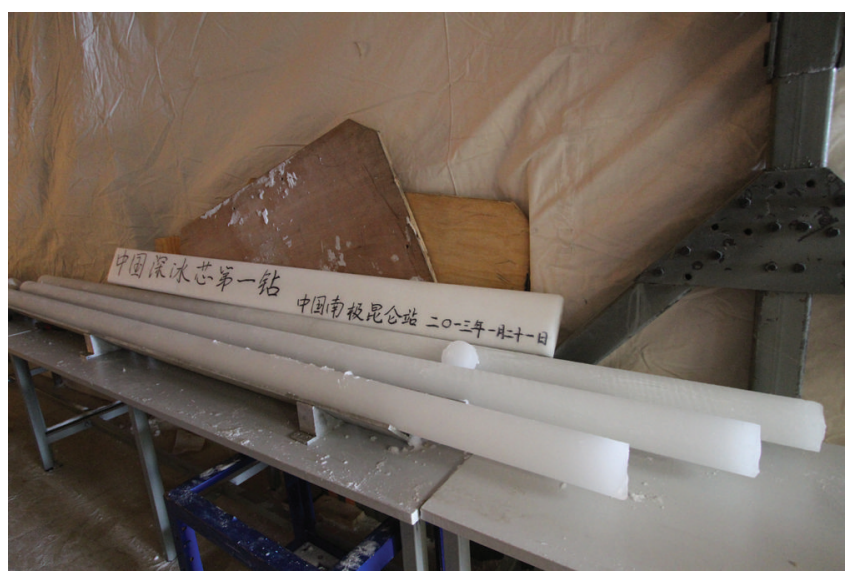

Fig. 16. Ice cores from 'wet' drilling (interval 120.79-131.24 m). cutter load and the rotation motor load was tested. A short $30 \mathrm{~mm}$ long testing run was carried out without drilling fluid.

Following the test run, $400 \mathrm{~L}$ of drilling fluid ( $n$-butyl acetate) was poured into the hole to $104 \mathrm{~m}$ depth. The drill was lowered and the change of cutter load when the drill was in the fluid and at the bottom was measured. The temperature at the bottom $(120.79 \mathrm{~m})$ was measured as $\sim-50^{\circ} \mathrm{C}$. The drill inclination at vertical free fall was acceptable $\left(x:-1.4\right.$ to $-1.0^{\circ}, y:-0.9$ to $\left.-0.5^{\circ}\right)$.

\subsection{Start of deep ice-core drilling}

Because of the short time in the field, only three runs, with a cumulative depth of $10.45 \mathrm{~m}$, were carried out (Table 6). The coring length was $10.99 \mathrm{~m}$ including an ice core remaining from the previous season (Fig. 16). During the ice-core drilling process, the lowering speed was kept at $0.3 \mathrm{~m} \mathrm{~s}^{-1}$, and the lifting speed at $0.34 \mathrm{~m} \mathrm{~s}^{-1}$. The lifting load

Table 4. Progress of the second drilling season at Kunlun station

Item

Date (2013)

Deep ice-core drill and auxiliary equipment

10-16 Jan installation

Equipment connection and debugging

Original parameters collection and test boring

Deep ice-core drilling 
Table 5. Technical parameters of electromechanical deep ice-core drilling rig (Operation/maintenance manual for CHINARE/JARE deep ice core drill system. 2011. Geo Tecs Co. Ltd, Nagoya)

\begin{tabular}{|c|c|c|}
\hline Item & & Technical parameters \\
\hline \multirow[t]{6}{*}{ Drill } & Main parameters & $\begin{array}{l}\text { Type: CHINARE/JARE deep ice drill; whole length: } 12223 \text { mm; } \\
\text { Core: } 94 \text { mm ID, } 3800 \text { mm long }\end{array}$ \\
\hline & Anti-torque & Leaf spring: 3 pcs, $700 \mathrm{~mm}$ long \\
\hline & Drive part & $\begin{array}{c}\text { Motor: permanent magnet-type d.c., model TM-80-50200 200 V/500 W } 4000 \text { rpm; decelerator: } \\
\text { harmonic drive system, reduction ratio 1/80; output: } 50 \text { rpm }\end{array}$ \\
\hline & Jacket & $123 \mathrm{~mm}$ OD, $4.5 \mathrm{~mm}$ thick, $4598 \mathrm{~mm}$ long, 6 ribs, made of high-strength aluminum \\
\hline & Chip chamber & $123 \mathrm{~mm}$ OD, $114 \mathrm{~mm}$ ID, $4.5 \mathrm{~mm}$ thick, $5000 \mathrm{~mm}$ long \\
\hline & Core barrel & $\begin{array}{c}101.6 \mathrm{~mm} \text { OD, } 2.1 \mathrm{~mm} \text { thick, } 4000 \mathrm{~mm} \text { long, } 3 \text { spiral windings of high-density polyethylene; } \\
\text { cutter mount: } 132 \mathrm{~mm} \text { OD, } 94 \mathrm{~mm} \text { ID }\end{array}$ \\
\hline \multirow[t]{3}{*}{ Winch } & Main parameters & $\begin{array}{c}\text { Type: CHINARE/JARE deep ice-drilling winch-4000; hoisting capability: } 1000 \mathrm{~kg} \text { (max } 1500 \mathrm{~kg} \text { ); } \\
\text { hoisting speed: } 0-60 \mathrm{~m} \mathrm{~min}^{-1}\end{array}$ \\
\hline & Cable drum & $\begin{array}{c}\text { Type: Rebus drum with groove, } 804 \mathrm{~mm} \text { wide, } 410 \mathrm{~mm} \text { OD of } 1 \text { st layer, } \\
\text { number of lines on the drum: } 100\end{array}$ \\
\hline & Motor & $\begin{array}{c}\text { Type: TIKK-EBKM8-4P-15kW, input: } 160 \mathrm{~V} 53 \mathrm{~Hz} \text { (inverter), output power: } 15 \mathrm{~kW} \text {, } \\
\text { motor rev: 0-1500 rpm (inverter control } 50 \mathrm{~Hz} \text { ), break: magnetic }\end{array}$ \\
\hline \multirow[t]{2}{*}{ Mast } & Mast top & $\begin{array}{c}400 \mathrm{~mm} \text { width, } 450 \mathrm{~mm} \text { height, } 2750 \mathrm{~mm} \text { length, top pulley: } 630 \mathrm{~mm} \text { OD, load cell with special } \\
\text { flange for connecting }\end{array}$ \\
\hline & Turnabout pulley on mast base & Pulley: $480 \mathrm{~mm}$ OD, with rotary encoders \\
\hline Cable & Main parameters & Armored cable $7.72 \mathrm{~mm}$ OD, $4000 \mathrm{~m}$ long \\
\hline \multirow[t]{5}{*}{ Control panel } & Drill control box & $\begin{array}{c}\text { Power supply: } 200 \mathrm{~V} \text { a.c. } 3 \text {-phase; output: drill motor, } 0-400 \mathrm{~V} \text { d.c.; component parts: slide } \\
\text { transformer, a.c. supply voltmeter, d.c. supply voltmeter, drill motor voltmeter and ammeter, drill } \\
\text { rev. meter, cutter load meter }\end{array}$ \\
\hline & Drill power unit box & $\begin{array}{c}\text { Power supply: } 200 \mathrm{~V} \text { a.c. 3-phase; components: slide regulator } 0-240 \mathrm{~V} \text {, transformer } 240-500 \mathrm{~V} \text {, } \\
\text { bridge rectifier, condensers }\end{array}$ \\
\hline & Winch control main box & $\begin{array}{l}\text { Power supply: } 200 \mathrm{~V} \text { a.c. 3-phase; output: inverter controlled; inverter: } 200 \mathrm{~V} 18.5 \mathrm{~kW} \text {; com- } \\
\text { ponents: magnetic contactor, power supply unit for brake, inverter }\end{array}$ \\
\hline & Break resistor unit box & Rating: $5280 \mathrm{~W}, 7.5 \Omega$ \\
\hline & Winch control box & $\begin{array}{l}\text { Power supply: } 200 \mathrm{~V} \text { a.c. 3-phase; component parts: cable load meter, cable speed meter, depth } \\
\text { meter, motor voltmeter, motor ammeter, inverter } \mathrm{Hz} \text {, isolation converter }\end{array}$ \\
\hline \multirow[t]{2}{*}{$\begin{array}{l}\text { Data monitoring } \\
\text { units }\end{array}$} & Data-sending unit (drill unit) & $\begin{array}{l}\text { Dimensions: cylindrical outer shape, length: } 490 \mathrm{~mm} \text {, diameter: } 80 \mathrm{~mm} \text {; power supply: d.c. } \\
200-400 \mathrm{~V}, 0.2 \mathrm{~A} \text { (without for a drill motor); sensing items: electric voltage of the drill motor, } \\
\text { rotation of the drill motor, contact pressure of the ice-coring section, inclination of the ice-coring } \\
\text { section (direction } x, y \text { ), temperature of the hole liquid, pressure of the hole liquid, leakage alarm of } \\
\text { the pressure-tight chamber, temperature of the drill motor, temperature of the reduction gear, } \\
\text { temperature of the CPU board, electric voltage of the data-sending unit }\end{array}$ \\
\hline & Data relay unit & $\begin{array}{l}\text { Dimensions: box shape, } 430 \mathrm{~mm} \text { width, } 430 \mathrm{~mm} \text { depth, } 150 \mathrm{~mm} \text { height (without connectors); } \\
\text { power supply: } 100 \mathrm{~V} \text { a.c. }( \pm 10 \%), 50 / 60 \mathrm{~Hz}, 1.5 \mathrm{~A} \text { (without the drilling motor current); } \\
\text { Sensing items: electric current of the drill motor, rectified electric voltage supplied for the drill } \\
\text { motor, air temperature at winch site, air temperature at drill site, temperature of the relay unit board; } \\
\text { communication: cable length: } 4000 \mathrm{~m} \text {, speed between the relay unit and the sending unit: } 600 \text { bps, } \\
\text { speed between the relay unit and PC: } 9600 \mathrm{bps}\end{array}$ \\
\hline
\end{tabular}

with ice core and chips was $\sim 1.6 \mathrm{kN}$, while the force of icecore breaking reached $2.4 \mathrm{kN}$. During the drilling process, the drill inclination was -1.6 to $-1.0^{\circ}$ in the $x$ direction and 1.1 to $-1.0^{\circ}$ in the $y$ direction.

Drilling was achieved with a cutter load of $30-60 \%$ of the drill weight and a motor current of 2-3 A. The highest motor rotation speed of $\sim 4000 \mathrm{rpm}$, which corresponds to a drill head rotation speed of $50 \mathrm{rpm}$, gave higher drilling efficiency. During the deep ice-core drilling process, some problems were encountered:

The tensile force of the anti-torque spring was adjusted as required. At the beginning of the first run, the motor current was $<2 \mathrm{~A}$, which is outside the normal working current range of $2-3 \mathrm{~A}$. It was identified that the antitorque spring had been adjusted to be too tight. When the drill was set near the bottom, the springs were blocked at the point where the first reaming finished. It was difficult to lower the drill any further. After lifting the drill and checking, it was found that the spring had been deformed. After adjustment, the cutter load kept increasing to $80 \%$ of the drill weight. It was concluded that the springs had been adjusted excessively. Finally, a proper tensile force was set, then the drilling process became normal.

Generally, the control system worked reliably except for the d.c. supply of the driven motor. At the beginning of the second run, the electrical supply relay was burnt out. After changing the relay, the motor worked normally.

Table 6. Deep ice cores

\begin{tabular}{ccccc} 
Run No. Drilling interval & Total run time & $\begin{array}{c}\text { Average rate of } \\
\text { penetration } \\
\mathrm{m} \mathrm{h}^{-1}\end{array}$ & $\begin{array}{c}\text { Core } \\
\text { length } \\
\mathrm{m}\end{array}$ \\
\hline 1 & min & & & \\
\hline 2 & $120.79-124.24$ & 43.5 & 4.74 & 3.83 \\
3 & $124.24-127.74$ & 43.7 & 4.80 & 3.57 \\
& $127.74-131.24$ & 44.3 & 4.74 & 3.59
\end{tabular}


During the drilling process, the frequency converter often stopped after a period of operation. It was found that when the temperature of the converter box increased, overheating protection was activated. Simply opening the cover of the box solved the problem.

\section{CONCLUSIONS AND FUTURE PLANS}

In January 2012 the Chinese Deep Ice Core Drilling Project DK-1 was formally started. After installation of the casing, three runs of 'wet' ice-core drilling were carried out and a depth of $131.24 \mathrm{~m}$ was reached. Generally, all systems and components worked well.

To speed up drilling progress, the logistics for Kunlun station are planned to be modified so that the field season duration can be increased to 1.5-2 months. Drilling to the bedrock down to nearly $3100 \mathrm{~m}$ depth is expected to be completed during the next four seasons. The successful fulfillment of drilling tasks during the first two seasons has established a firm foundation for future work.

\section{ACKNOWLEDGEMENTS}

The fieldwork and research introduced in the paper were supported by various funds, including Chinese Polar Environment Comprehensive Investigation and Assessment Programmes (No. CHINARE2014-02-02 and No. CHINARE2014-94-02-07), Public Science and Technology Research Funds Projects of Ocean (No. 200805001), National Nature Science Foundation of China (No. 41327804) and Chinese Polar Science Strategy Research Fund - Young Talent Fund (No. 20120313). The field personnel overcame the major difficulties of lack of oxygen and extremely low temperatures in inland Antarctica. We thank $\mathrm{H}$. Motoyama of the National Institute of Polar Research, Japan, and Japanese drilling experts Y. Tanaka, M. Miyahara and A. Takahashi for help with the drilling technology design and training. Authors also thank the teammates and machinists of the 28th and 29th CHINARE team who provided excellent logistic support for the fieldwork of the Chinese Deep Ice-Core Drilling Project.
We also acknowledge David Blake of the British Antarctic Survey for editing the paper.

\section{REFERENCES}

An CL and Li YS (unpublished) 2011-2012 practice scheme of deep ice core drilling construction at Kunlun Station. Polar Research Institute of China, Shanghai [in Chinese]

EPICA Community Members (2004) Eight glacial cycles from an Antarctic ice core. Nature, 429(6992), 623-628 (doi: 10.1038/ nature02599)

EPICA Community Members (2006) One-to-one coupling of glacial climate variability in Greenland and Antarctica. Nature, 444(7116), 195-198 (doi: 10.1038/nature05301)

Hou S, Li Y, Xiao C and Ren J (2007) Recent accumulation rate at Dome A, Antarctica. Chinese Sci. Bull., 52(3), 428-431 (doi: 10.1007/s11434-007-0041-3)

Jones N (2007) Polar research: buried treasure. Nature, 446(7132), 126-128 (doi: 10.1038/446126a)

Motoyama H (2007) The second deep ice coring project at Dome Fuji, Antarctica. Sci. Drilling, 5(5), 41-43 (doi: 10.22 04/iodp. sd.5.05.2007)

Nature (2006) News in brief. China set to drill for Antarctica's oldest ice. Nature, 444(7117), 255-255 (doi: 10.1038/444255a)

Petit JR and 12 others (1997) Four climate cycles in Vostok ice core. Nature, 387(6631), 359-360

Qin D (1991) Development, hot spots and prospects of Antarctic glaciology. Adv. Earth Sci. [China], 6(3), 38-43

Ren J, Xiao C, Hou S, Li Y and Sun B (2009) New focuses of polar ice-core study: NEEM and Dome A. Chinese Sci. Bull., 54(6), 1009-1011

Talalay PG and Gundestrup NS (1999) Hole fluids for deep ice core drilling: a review. University of Copenhagen, Copenhagen, 16-65

Tang H-Y, Xun B, Li Y, Cui X and Li X (2012) Review of the glaciological research progress and future development of deep ice core plan at Dome A, East Antarctica. Adv. Polar Sci., 24(1), 77-86 (doi: 10.3724/SP.J.1084.2012.00077)

Tang X, Sun B, Li Y, Li X and Cui X (2012) Dome Argus: ideal site for deep ice drilling. Adv. Polar Sci., 23(1), 77-86 (doi: 10.3724/ SP.J.1085.2012.00047) [in Chinese with English summary]

Xiao C, Li Y, Hou S, Allison I, Lingen B and Ren J (2008) Preliminary evidence indicating Dome A (Antarctica) satisfying preconditions for drilling the oldest ice core. Chinese Sci. Bull., 53(1), 102-106 (doi: 10.1007/s11434-007-0520-6)

Yao T (1998) Ice core study of the Tibetan Plateau. J. Glaciol. Geocryol., 20(3), 233-237 [in Chinese with English summary] 